\title{
STABILITY ANALYSIS Of 20 kVSYSTEMat PT PLN (PERSERO) RAYON MUARALABUH BEFORE and AFTER INTERCONECTION by IPP (PLTMH PT. SKE)
}

\author{
Arfita Yuana Dewi, Asnal Effendi, Ridwan \\ InstitutTeknologi Padang. Electrical Engineering department, Padang, West Sumatra, Indonesia
}

\begin{abstract}
In the rapid development of the world as it is today, the electricity has a very important role in supporting people activities. PT PLN (Persero), which in this case as Government State Owned Company that directly manage the provision of electrical energy is required to be ready to face the development of electricity demand in Indonesia. In distribution system of electricity, problems often occure because of the length of line distribution system which cause voltage drop, technical losses, power losses, etc. One of them happened to PT PLN (Persero) Rayon Muaralabuh. Where the distance between the main substation (GI Solok) with the first connecting substation is $\pm 110 \mathrm{KMS}$. This distance cause $9.62 \%$ voltage drop during peak load. This nominal of voltage drop happens for just the first connecting substation that will be the source of division for all working areas of PT PLN (Persero) Rayon Muaralabuh. This factor encourages PT PLN (Persero) West Sumatra Area Solok to agree if Independent Power Plant (IPP) takes part in generating electricity, which will be distribute to PT. PLN (Persero) West Sumatera Area Solok Rayon Muaralabuh through interconnection system. The simulation of power flow using Etap 12.6.0 is used to analyze the stability of $20 \mathrm{kV}$ system voltage at PT PLN (Persero) Rayon Muaralabuh before and after interconnection. Based on the result of simulation and Etap calculation, the highest voltage drop before interconnection by IPP is on Feeder express LubukGadang which is $13,71 \%$. After the interconnection by IPP, the voltage drop on that feeder becomes $4,326 \%$, and the highest voltage drop is $4,855 \%$. Therefore, the voltage drop after the interconnection by the IPP already meets the standards allowed by SPLN No. 72 of 1987 which is maximum $5 \%$ voltage drop. The precentage of technical losses in PT PLN (Persero) Rayon Muaralabuh before interconnection is 13,074 \%, and after interconnection is decreased to $8,306 \%$.
\end{abstract}

\section{INTRODUCTION}

In the rapid development of the world as it is today, electricity has a very important role in supporting people activities. People needs electricity can be seen in daily life, such as : lighting, electronic devices, industries, communications, and etc.PT PLN (Persero), which in this case as Government State Owned Company that directly manage the provision of electricity is required to be ready to face the development of electricity demand in Indonesia.

Provision of electricity by PT PLN (Persero) to consumer through several stages. Beginning with power generation, the electricitywhich has been generated will be raised into High Voltage (HV) then transmitted through the transmission line. After that the voltage of this electricity will be reduced into medium voltage, then it will be distributted to the substation. To fulfill low voltage consumers demands electricity from medium voltage will be distributted to distribution transformator in order to reduce the voltage into low voltage.

In the distribution system of electricity, problems often occur due to the length of the distribution line resulting some impacts, including; drop voltage, technical losses, power losses, etc.These impacts encourages PT PLN (Persero) West Sumatra Area Solok to agree if Independent Power Plant (IPP) takes part in generating electricity, which will be distribute to PT. PLN (Persero) West Sumatera Area Solok Rayon Muaralabuh through interconnection system. Where the distance between the main substation (GI Solok) to first connecting substation is \pm 110 KMS

Thelong-distance of distribution from GI Solok to PT PLN (Persero) Rayon Muaralabuhcauses voltage drop that receivedby PT PLN (Persero) Rayon Muaralabuh. Where, Outside Peak Load Time (LWBP) the send voltage of GI Solokis $20.4 \mathrm{kV}$ and received in PT PLN (Persero) Rayon Muaralabuh only $18.7 \mathrm{kV}$, which means voltage drop reaches $8.33 \%$. Peak load time (WBP) of send voltage from GI Solokis $20.8 \mathrm{kV}$ and received in PT PLN (Persero) Rayon Muaralabuh only $18.8 \mathrm{kV}$, which means voltage drop reaches $9.62 \%$. The voltage received in PT PLN (Persero) Rayon Muaralabuhis just incoming voltagefor GH Balun which is the source of distribution for all working areas in PT PLN (Persero) Rayon Muaralabuh.

IPP (Independent Power Producer) which in this case is PT SeloKencana Energy (SKE), is a private company which works in Micro Hydro Power Plant (PLTMH). This power plant began operation in 2013. The operation pattern of this power plant is parallel to the 20 $\mathrm{kV}$ system of PT PLN (Persero) Rayon Muaralabuh also called interconnection system. With the existence of Micro 
Hydro Power Plant (PLTMH) owned by PT SeloKencana Energy which is interconnected with PLN's $20 \mathrm{kV}$ system, it is very helpful for PT PLN (Persero) Rayon Muaralabuh to fulfill electricity demand in Solok Selatan District which reaches 7.8 MW during peak load. The power plant owned by PT SeloKencana Energy with 2 X 4 MW capacity, has participated together with PT PLN (Persero) Rayon Muaralabuhto reduce voltage drop, technical losses for South Solok Regency and surrounding areas.

Before the interconnection with private power plants PT. SKE, medium voltage distribution system of PT PLN (Persero) Rayon Muaralabuh is assisted by PLTD Balun with 2 X 1 MW operating capacity. PLTD Balun is a privately-owned machine with lease status at PT PLN (Persero). The existence of 2 units of operation and 1 unit of standby of PLTD machine is not enough to help PT PLN (Persero) Rayon Muaralabuh system to fulfill consumer needs.As evidenced is the "rotating blackout" system at PT PLN (Persero) Rayon Muaralabuh.

With the interconnection on $20 \mathrm{kV}$ system with IPP (Independent Power Producer) is very helpful for PT PLN (Persero) Rayon Muaralabuh to fulfill electricity needs in South Solok district which is increasing from time to time, with service voltage that meets the standard.

This study aims to analyze the stability of $20 \mathrm{kV}$ System Voltage at PT PLN (Persero) Rayon MuaralabuhBefore And After Interconnection With IPP (PT SKE).

\section{BASIC THEORY}

The distribution system is the whole component of a power system that connects directly between large power sources (such as transmission substations) with electricity consumers (Figure 2.1) shows a series of power distribution systems.

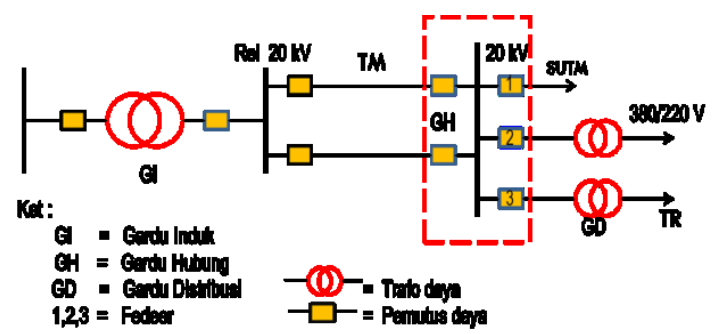

Fig.1One-Line Diagram of Electrical Power Distribution System

The distribution network generally consists of two parts, namely as follows:

1. Primary Distribution System

Namely power system that distributes electricity from the sub transmission substation (GI) to the distribution substation $(\mathrm{GH})$. This system is a medium voltage (JTM) or primary voltage system.

2. Secondary Distribution System

Namely the power system that distributes electricity from the distribution substation $(\mathrm{GH})$ to the consumer. This system is often called the low voltage system (JTR).

\subsection{Primary Distribution System Types}

In this service the primary distribution system has several variations of form, where each form of system has several advantages and disadvantages. In general there are four basic forms of primary distribution network system which are :

1) Radial primary distribution system

2) loop / ringprimary distribution system

3) Primary ring distribution system

4) Primary grid (network)distribution system

5) Spindle and clusterdistribution system.

\subsubsection{Radial Primary Distribution System}

This radial primer network is the most common and commonly used form, mainly used in load areas with low load density. This system has one power line to the load, then all the load on the channel will lose power when a channel is interrupted.

The main advantage of this radial system is its simple shape and low cost. The weaknesses of the system is the continuity of service is bad, low reliability, and high voltage drop, especially for the at the end of the distribution line. The large current density of this type of radial is found in the line between the power source and the substation and the smallest happens at the end of the line. In accordance with the level of current density, the cross-sectional area may vary. The primary radial type distribution network is represented by (Fig. 2).

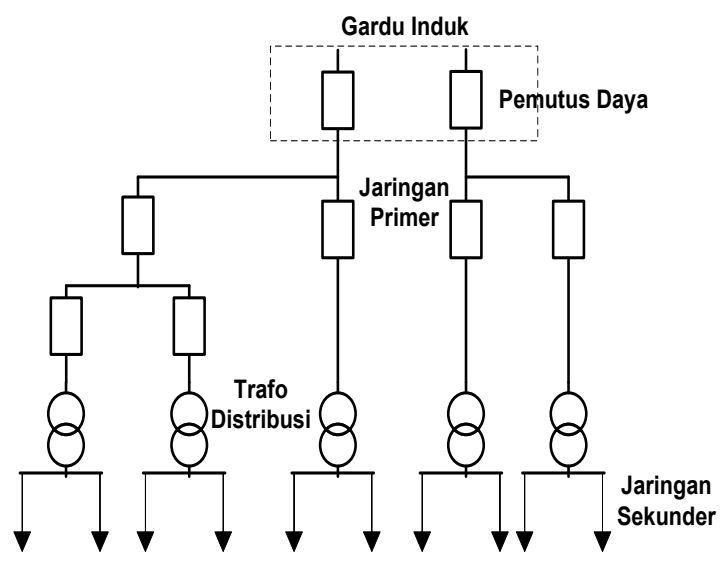

Fig. 2Radial Primary Distribution System

\subsubsection{Loop Primary Distribution System}

Loop primary distribution system is typically used to serve loads that require good service continuity such as: Commercial buildings or factories with medium and large loads. In principle, the primary distribution line of the loop type is a line that starts from a point or rail to the load zone, then returns to the source point of the rail or the original power. In Medium Voltage Network (JTM) loop structure, enabling an alternative power supply for distribution substations, so that the system reliability is better.

In case of power disturbance with one of the feeders, the 
load breaker in the GI will open and this will cause blackout in all distribution systems. Faced with these conditions, the action to be taken is to ensure and localize the power disturbance areas. Furthermore, areas that are not involved in power disturbance can be supplied from other feeders. Loop distribution linealso needs attention in short circuit current which is big .

Medium Voltage Line Configuration (JTM) loop structure, of course very desirable by all units of PLN. Because loop distribution linehas more advantages when compared with radial systems, the loop system can also promote to customers of PLN, especially large-capacity customers to be proposed to become a premium customer. Where one of the absolute conditions for premium customers is supported from 2 (two) different sources. The loop-type distribution network is shown by (Fig. 3).

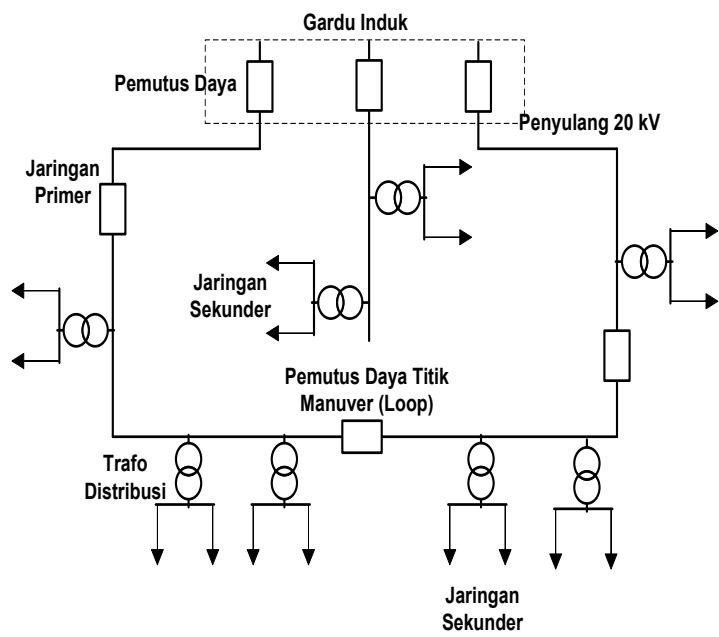

Fig. 3.Loop Primary Distribution System

\subsubsection{Ring Primary Distribution System}

Ringprimary distribution system is generally similar to loop type distribution line, the difference is only the number of resources more than one. In other words, The primary ring type distribution line is a loop type whose distribution substations can receive more power than a single source point. The primary line type distribution lineoften develops into a grid shape. The following is The primary line type distribution line (Fig. 4).

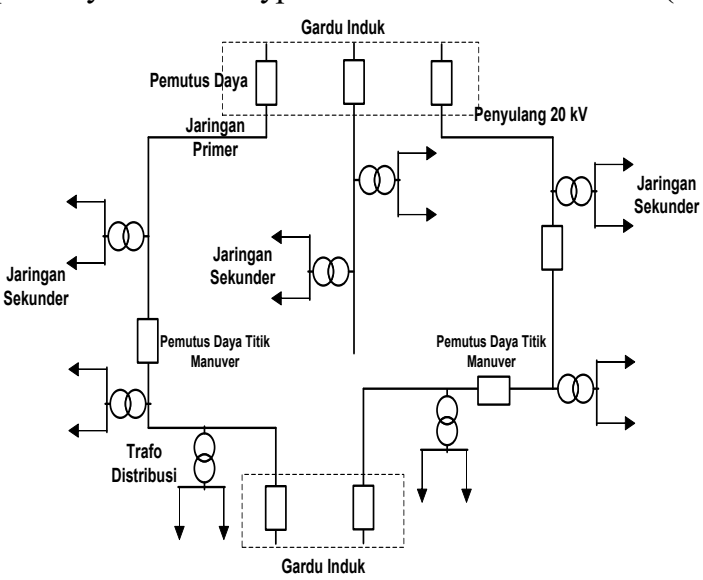

Fig.4. Ring Primary Distribution System

\subsubsection{Grid Primary Distribution System}

This system is an interconnection between some substations (GI) so that the load will receive power from various directions. Reliability of this system if there is power disturbance on one feeder, the consumer will still be supplied from other feeder so that the customer still served. Development of this type of distribution network would require large cost, because there are many substations needed. Primary grid type distribution line as in (Fig. 5).

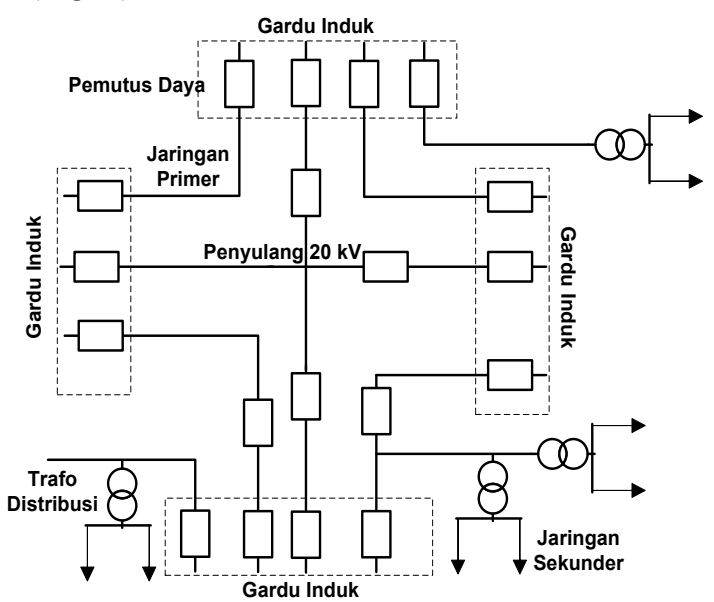

Fig.5. Grid Primary Distribution System

\subsubsection{Spindle and Cluster Primary Distribution System}

In this system is often used in big cities, this system is the development of radial system. Power will be supplied from power plants or substations through some feeder or distribution substations and ends in switching substation. The specialty of this system is the presence of a free line that is not burdened by any load which will be the immediate reserve lineto reflection substation with the shortest path. For normal conditions on this system all switches on the reflection will be in open condition and if a system is not using a reflection substation, but the feeder state is primarily connected to the backup line then this is called the cluster type. While the spindle type system uses a substation reflection as it should. The primary spindle distribution line is found in (Fig. 6) and the cluster type distribution line as seen in (Fig. 7).

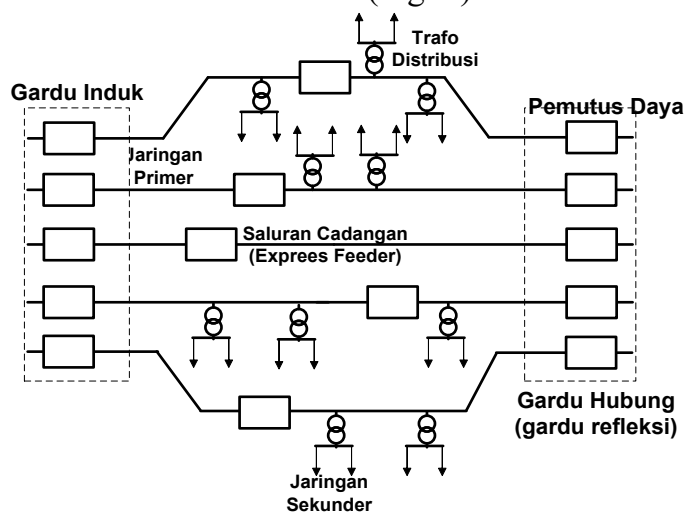


Fig.6. Spindle Primary Distribution System

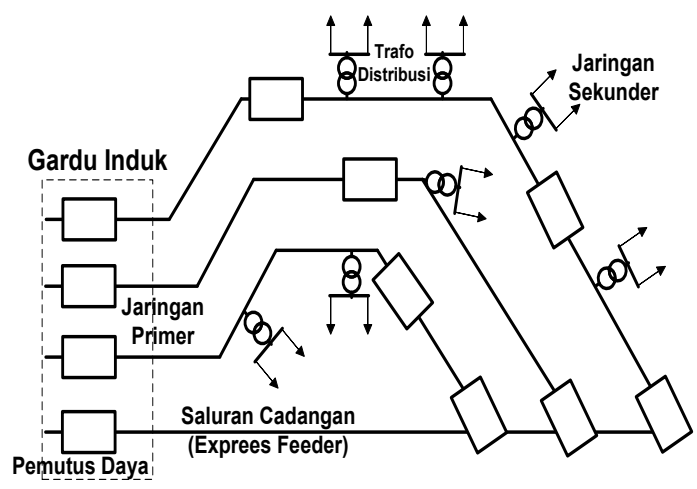

Fig.7. Cluster Primary Distribution System

\subsection{Voltage Drop}

The voltage drop is the voltage loss between the send/source voltage and the receive voltage. The voltage drop is caused by the resistance and current on the alternating line, the magnitude dependson the impedance and the power factor at the load. Power lines generally serve loads that have lagging power factor. The factors that caused the difference of voltage distribution system are:

1. Consumers have equipment that requires a certain voltage.

2. Location of the consumer spread, so the distance of each customer with the point of service is not the same.

3. The occurrence of voltage drop.

Voltage drop in distribution line can also be said to be a loss of power during power delivery. The magnitude of the voltage drop depends on the amount of load current flowing on the distribution line, the length of the distribution line and the type of wire to deliver the load.

The voltage drops allowed under SPLN No. 72 of 1987 are as follows:

1) $\mathrm{SUTM}=5 \%$ from voltage line in radial system

2) $\mathrm{SKTM}=2 \%$ from voltage line inspindle and gugus system

3) Distribution Transformator $=3 \%$ from volatge line

4) SUTR $=4 \%$ from volatge line

5) SambunganRumah $=1 \%$ from minimum voltage line

Drop Voltage formula :

$$
\begin{aligned}
& \text { Vdrop }=\mathrm{I} \times(\mathrm{R} \operatorname{Cos} \varphi+\mathrm{X} \operatorname{Sin} \varphi) \times \ell \\
& \quad=(\mathrm{I} . \mathrm{Z}) \mathrm{x} \ell \\
& \quad=(\mathrm{Vs}-\mathrm{VR}) \\
& \mathrm{Vs}=\mathrm{VR}+(\mathrm{I} . \mathrm{Z}) \\
& \mathrm{Vs}=\mathrm{VR}+\text { Vdrop }
\end{aligned}
$$

Percentage Drop Voltage Formula ::

(Vdrop) $\%=\frac{\text { Vdrop }}{\text { Vs }} \times 100 \%$

Where :

Vs $=$ Voltage Source

VR $=$ Voltage Receive
(Vdrop) $\%=$ Precentage Voltage Drop (\%)

I $=$ Load current (A)

$\mathrm{Z} \quad=$ Impedance

$\ell \quad=$ Length of the channel $(\mathrm{m})$

$\mathrm{V} \quad=$ Voltage $(\mathrm{V})$

$\mathrm{R}=$ Conductive Resistance $(\Omega)$

$\mathrm{X} \quad=$ Conductor Inductive Reactance $(\Omega)$

$\operatorname{Cos} \varphi=$ Power factor

$\operatorname{Sin} \varphi=$ Sinus angle of load

$\varphi=$ phase angle of load

1. Conductor

2. Length of the channel

3. Wire Size

4. current carrying capacity

\subsection{Power Losses}

Power loss is the amount of electricity lost during the delivery of electricity in a certain time (usually in the watthour). This loss is influenced by the amount of difference between the received power and the power sent. The magnitude of 3 phase power can be seen from the following formula:

$P 3 \phi=\sqrt{3} \cdot(V(L-L) x I) \cdot \operatorname{Cos} \varphi$

$=\sqrt{3} \cdot(\sqrt{3} \cdot V(L-N) x I) \cdot \operatorname{Cos} \varphi$

$$
=3 \cdot V(L-L) \times I x \operatorname{Cos} \varphi
$$

Where :

$$
\begin{aligned}
& \text { P } 3 \phi=3 \text { phase power (Watt) } \\
& \text { V L-L }=\text { voltage phase-phase } \\
& \text { V L-N }=\text { Voltage Phase-Neutral } \\
& \text { I }=\text { Load Current (Ampere) } \\
& \operatorname{Cos} \varphi=\text { Power Factor }
\end{aligned}
$$

Factors that caused power losses are :

1. Power losses in distribution system

Three phase Power losses with load at the end of the line:

So the Energy Losses is :

$$
\begin{aligned}
\text { P Losses } & =(\mathrm{Ps}-\mathrm{PR}) \\
& =\left(\mathrm{I}^{2} \times \mathrm{Z} \text { Total }\right) \\
& =\mathrm{I}^{2} .(\mathrm{R} \cdot \operatorname{Cos} \varphi+\mathrm{jX} \cdot \operatorname{Sin} \varphi) . \ell
\end{aligned}
$$

Where :

$$
E=(P \text { Losses } x t)
$$

P Losses $=$ Power losses $($ Watt $)$

Ps $=$ Power sent (Watt)

$\mathrm{PR}=$ Power received $($ Watt $)$

$\mathrm{I}=$ Current (Ampere)

$\mathrm{Z}=$ Impedance $(\Omega)$

$\mathrm{R}=$ Conductive Resistance $(\Omega)$

$\mathrm{X}=$ Conductor Inductive Reactance $(\Omega)$

$\operatorname{Cos} \varphi=$ Power factor

$\operatorname{Sin} \varphi=$ Sinus angle of load

$\varphi=$ phase angle of load

$\ell=$ length of the channel $(\mathrm{km})$

$\mathrm{t}=$ time (jam/killo Watt)

2. Unbalanced Load.

3. Error in $\mathrm{kWh}$ meter.

4. Loss contact.

5. Ireegular use of electricity. 


\subsection{Electric Transient and Analysis Program (ETAP) 12.6.0}

ETAP 12.6.0 is a comprehensive analysis software to design and simulate a power supply system. The analysis offered by ETAP used by the authors is the voltage drop, and the network losses. ETAP also provideS a warning to undervoltage and overvoltage bus so can be known which bus is not in optimal operation.In order to analyze a series of circuitneeds complete and accurate circuit data so the calculation from ETAP can be answered.

\section{ANALYSIS}

To complete the data needed in the analysis and calculation required data in accordance with the purpose of the study. The data is taken in accordance with the research which from data distribution system PLN Rayon Muaralabuh. The data are as follows:

1. Data of all feeders at Rayon Muaralabuh and MuaralabuhExpress Feeder GH AlahanPanjang.

2. Table impedance JTM type AAAC

3. Transformer data of all related feeders

4. The peak load data of each related feeder.

\subsection{Distribution Operation Pattern}

Condition before interconnection with IPP (PLTMH PT SKE). The condition of $20 \mathrm{kV}$ system at PT PLN (Persero) Rayon Muaralabuhbefore interconnection with IPP of Hydro Micro Power Plant (PLTMH) owned by PT SeloKencana Energy, Rayon Muaralabuh system assisted by two units of PLTD owned by PT. SINARINDO, as shown in Fig. 9.

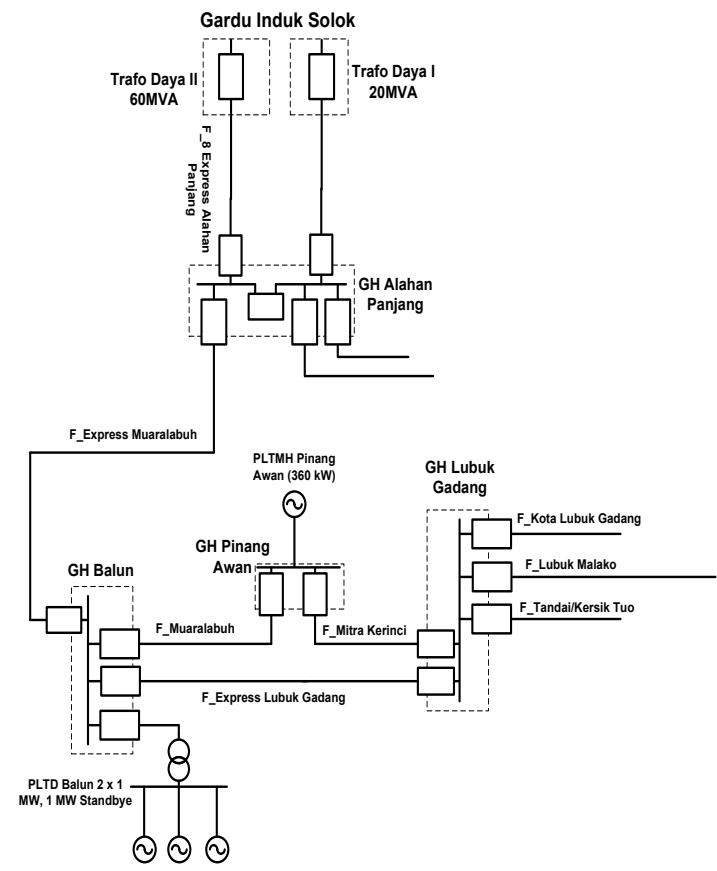

Fig. 9. Single Line Diagram Muaralabuh before interconnection
As shown in Figure 4.1, the distribution system of $20 \mathrm{kV}$ PT PLN (Persero) Rayon Muaralabuh is supplied by one unit of substation (GI) that is GI Solok. In GI Solok there are two units of power transformer that serves to lowered the high voltage $150 \mathrm{kV}$ transmission into medium voltage distribution $20 \mathrm{kV}$. Power Transformator I with a capacity of 20 MVA while PowerTransformator II with a capacity of $60 \mathrm{MVA}$. For distribution system $20 \mathrm{kV}$ PT PLN (Persero) Rayon Muaralabuh, suported by power transformator II (Bus II) through feeder 8 express AlahanPanjang to the Alahan Panjang Substation. Furthermore, from AlahanPanjangSubstationuntil working area of PT PLN (Persero) Rayon Muaralabuh distributed through feeder express AlahanPanjang.

At GH Alahan Panjang other than incoming feeder 8 express Alahan Panjang, there is also incoming from feeder 4 MuaraPanas which is sourced from bus I GI Solok, this become supply for two outgoing feeder at $\mathrm{GH}$ AlahanPanjang. Two outgoing feeder is working area PT PLN (Persero) Rayon KayuArowhich are: FeederTalangBabungo and FeederSungaiNanam. These Feeders allow to manuver the $20 \mathrm{kV}$ supply system at PT PLN (Persero) Rayon Muaralabuh, if there is any power disturbance to feeder 8 Express GI Solok until GH Alahan Panjang.

Sistem distribusi $20 \mathrm{kV}$ pada PT PLN (Persero) Rayon Muaralabuh ini masih menggunakan sistem radial.Hal ini disebabkan karena sistem $20 \mathrm{kV}$ PT PLN (Persero) Rayon Muaralabuh hanya disupplay oleh satu unit gardu induk.Oleh karena itu tingkat kehandalannya rendah.

The conductor that is used in Feeder 8 Alahan Panjangfrom GI Solok until GH Alahan Panjang is AAAC $240 \mathrm{~mm}^{2}$. The conductor that is used in Feeder 8 Alahan Panjangfrom GH Alahan Panjang until GH Balun is AAAC $150 \mathrm{~mm}^{2}$ on the main line, while in the branch use AAAC $70 \mathrm{~mm}^{2}$ AAAC $35 \mathrm{~mm}^{2}$. This causes the voltage drop in the substation receiver at PT PLN (Persero) Rayon Muaralabuh large enough.

\section{A. Kondisisesudahinterkoneksidengan IPP (PLTMH PT} SKE)

The condition of $20 \mathrm{kV}$ system at PT PLN (Persero) Rayon Muaralabuh after the interconnection with IPP which in this case is Hydro Micro Power Plant (PLTMH) owned by PT SeloKencana Energy, as shown in Fig. 10. 


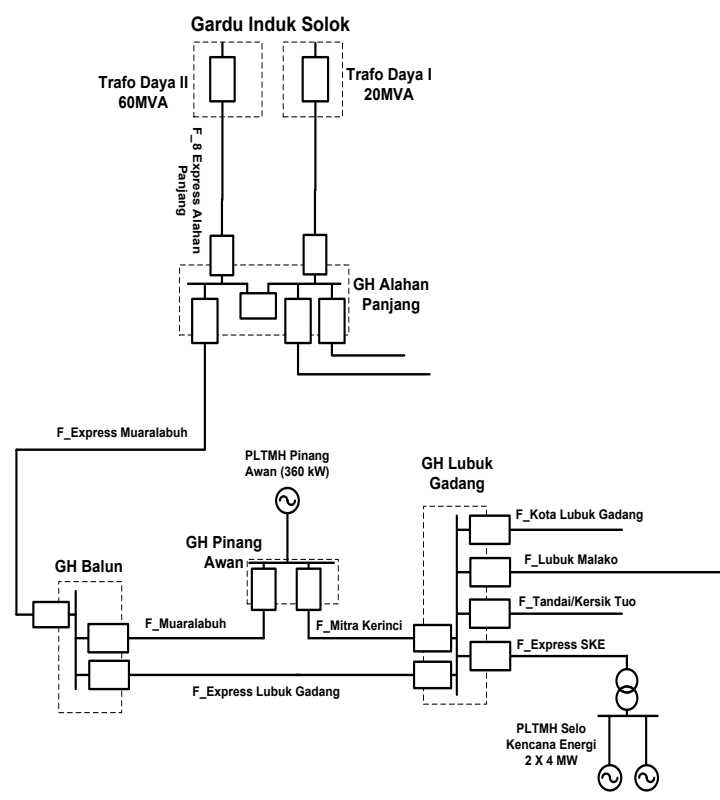

Fig.

10. Single Line Diagram Muaralabuh after interconnection

\subsection{Calculation Using Etap 12.6.0 Simulation}

Calculation with etap simulation adjusted for research purposes, that is as follows:

1. Calculate the percentage of voltage drop on $20 \mathrm{kV}$ system PT PLN (Persero) Rayon Muaralabuh (using Etap12.6.0 simulation)

2. Calculate technical losses on the $20 \mathrm{kV}$ system of PT PLN (Persero) Rayon Muaralabuh (using Etap12.6.0 simulation)

3. Calculate the stability of $20 \mathrm{kV}$ system voltage at PT PLN (Persero) Rayon Muaralabuh before and after interconnection with IPP (PLTMH PT SKE) (using equation and Etap simulation 12.6.0).

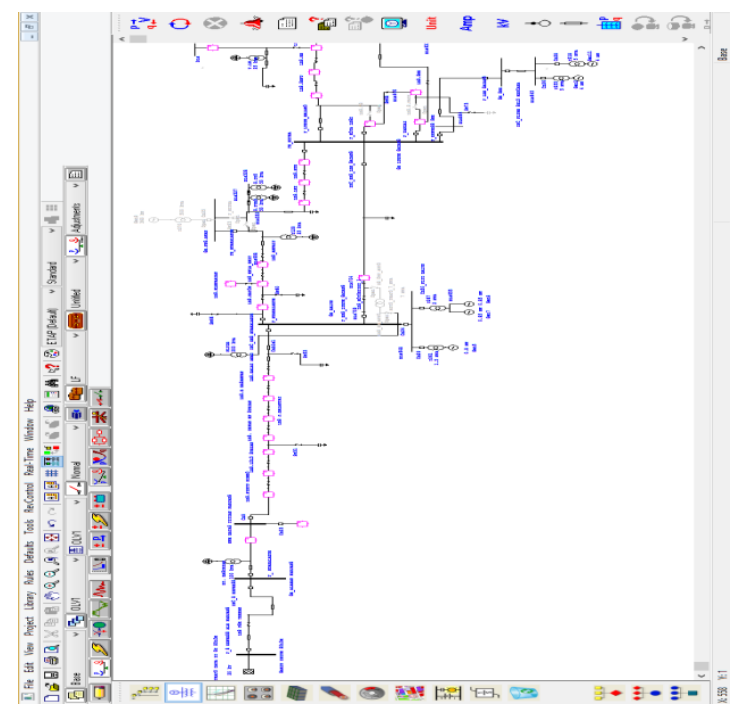

Fig. 11. Single Line Penyulang Rayon MuaralabuhDenganEtap

After creating a single line diagram distribution system of Rayon Muaralabuh in Etap, proceed with input value; load capacity on distribution transformers, source voltage, channel length and the type of conductor used. After that simulation of power flow on $20 \mathrm{kV}$ system of PT PLN (Persero) Rayon Muaralabuh by clicking the load flow analysis toolbar. Here is the result of power flow simulation on $20 \mathrm{kV}$ distribution system PT PLN (Persero) Rayon Muaralabuh using Etap 12.6.0.

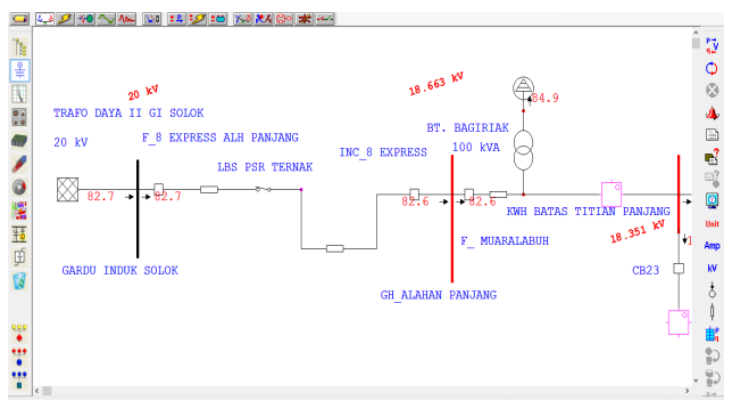

Fig. 12.Simualtion Result Drop Voltageat GI Solokdan GH AlahanPanjang

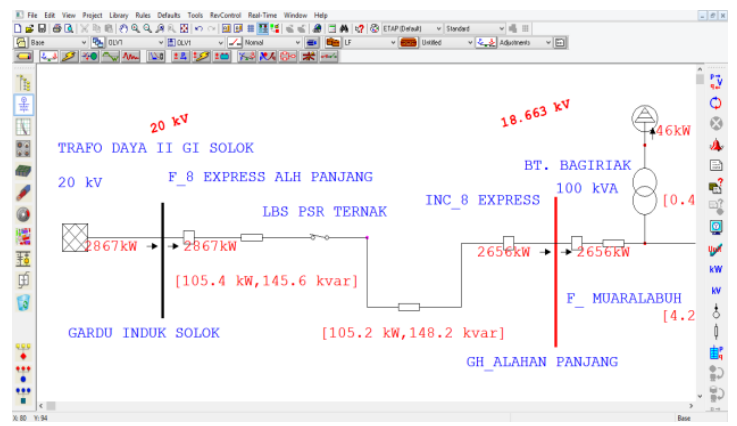

Fig. 13. Simulation Result Technical Losses at Feeder 8 Express AlahanPanjang

From simulation and calculation results with Etap 12.6.0, so can be made data table comparison measurement and calculation of voltage drop, technical losses and $20 \mathrm{kV}$ system voltage stability at PT PLN (Persero) Rayon Muaralabuh before and after interconnection with IPP ( PLTMH PT SKE) as follows:

Based on the comparison table between the calculation usingetap with validation formula above, it can be shown that the difference between the two calculations does not exceed $1 \%$ (one percent). So it can be stated that the result of calculation of voltage stability with Etap 12.6.0 simulation, can be a benchmark for performing voltage stability analysis.

\subsection{Saving Power}

Saving Power is the amount of loss (measured by the value of power) that can be saved or reduced as a result of a program or activity, which if the activity is not executed will condition.

From the calculation of technical losses before and after interconnection with IPP (PLTMH PT SKE), it can be calculated saving power in one month (number of days 
30) regardless of point of transaction with power plant, as follows:

$$
\begin{aligned}
\text { E1 } & =857.808 \mathrm{kWh} / \text { month } \\
\text { E2 } & =573.840 \mathrm{kWh} / \text { month } \\
\text { Esaving } & =\mathrm{E} 1-\mathrm{E} 2 \\
& =857.808-573.840 \\
& =283.968 \mathrm{kWh} / \text { month. }
\end{aligned}
$$

\subsection{Saving Cost}

Saving cost is defined as a loss (measured by monetary value) that can be saved or deducted as a result of a program or activity, which if the activity is not executed will cause harm or remain the same as the previous state. In this discussion, saving cost is calculated based on sent energy that can be saved (which has been lost) and multiplied by the average price of energy per kWh at PT PLN (Persero) Rayon Muaralabuh in that period.

With the change of operation pattern of distribution system of $20 \mathrm{kV}$ at PT PLN (Persero) Rayon Muaralabuh which interconnect with IPP (PLTMH PT SKE) hence $283,968 \mathrm{kWh} /$ month reducement of technical losses. If this amount multiplied by the average price of energy per kWh at PT PLN (Persero) Rayon MuaralabuhRp 926, then get a saving cost of Rp 262.954.368, - per month.

\section{CONCLUSION}

1. The highest voltage drop of distribution system $20 \mathrm{kV}$ at PT PLN (Persero) Rayon Muaralabuh before interconnection with IPP (PLTMH PT SKE) based on the result of simulation Etap 12.6 .0 is $13.71 \%$, while after interconnection down to $4.855 \%$. The condition after this interconnection, in accordance with the standard voltage drop on SPLN No. 72 of 1987 is a maximum of $5 \%$

2. Technical losses of $20 \mathrm{kV}$ distribution system at PT PLN (Persero) Rayon Muaralabuh before interconnection with IPP (PLTMH PT SKE) based on simulation result of Etap 12.6.0 ignoring transaction point $13.074 \%$ while after interconnection down to $8,306 \%$. This number explains that the decreasement of $20 \mathrm{kV}$ losses in PT PLN (Persero) Rayon Muaralabuh after interconnection with IPP (PLTMH PT SKE) is $4,768 \%$.

3. Percentage of $20 \mathrm{kV}$ system voltage stability at PT PLN (Persero) Rayon Muaralabuh after interconnection with IPP (PLTMH PT SKE) based on result of simulation Etap 12.6.0 is equal to $10,576 \%$ better.

4. Saving energybecause of the interconnection system (ignoring the point of transaction based on the result of
Etap 12.6.0 calculation) in one month is $283,968 \mathrm{kWh}$. This number explains that saving cost or rupiah saved at PT PLN (Persero) Rayon Muaralabuh after interconnection with IPP (PLTMH PT SKE) in one month (reference to rupiah average per $\mathrm{kWh}$ at PT PLN (Persero) Rayon MuaralabuhRp926 ), - is Rp 262,954,368, -.

\section{REFERENCES}

1. Basri, Hasan (1997): Power System Distribution. Jakarta: ISTN.

2. Hasyim'ari, Jatmikodan Ivan BachtiarRivai (2003): Drop Voltage Reapair for Consumer. Surakarta: MuhammadiyahUniversity

3. Malik, Muh. Nasir (2009): Losses Analysis Primary Distribution in Adhyaksa Makassar Feeder. Makassar: MakassarUniversity.

4. Utomo, HendroWahyu (2010): Analysis of Power Losses and Voltage Profilein APJ Surakarta. Surakarta: MuhammadiyahUniversity

5. Pitoy, RanggaSenando (2016): Analysis of Energy Losses in Distribution Network. Manado: PoliteknikNegeri.

6. Rahman, Fadli (2017): Analysis of express feeder building to Load Flow in Sungai Dareh Feeder at PT PLN (Persero) Rayon Sitiung. Padang. InstitutTeknologiof Padang.

7. S, Alfredo Donald andEdyErvianto (2016): Analysis Study of Power Losses : Load Curve Approachin PT. PLN (Persero) Area Pekanbaru. Pekanbaru: RiauUniversity

8. Sampeallo, Agusthinus S., Wellem F. GalladanRendi A. Oematan (2013): Analysis of Voltage Drop $20 \mathrm{kV}$ System Based on Load Change (Study Case Penfuiand Oebobofeeder PT PLN (Persero) Rayon Kupang). Kupang: Nusa Cendana University.

9. SPLN (1985) No. 64: Instructions for Selectionand Use of Fuser In Medium Voltage Distribution System : PT PLN (Persero) Jakarta

10. SPLN (1987) No. 72: Design Specification For Medium Voltage Network (JTM) And Low Voltage Network Jakarta: PT PLN (Persero) Jakarta.

11. Waluyo, Soenarjo dan Andi Ali Akbar (2007): Calculation of Power Shuts On Medium Voltage Distribution System of Air and Cable Channels

12. Bandung: ITENAS.

13. Winardi, Bambang, Agung Warsito dan Meigy Restanaswari Kartika (2015): Technical Shock Improvement Analysis and Suspense Voltage on Repeater KLS 06 in GisKalisari Using Etap Software 7.5.0.Semarang: DiponegoroUniversity. 